\title{
Membangun Komunikasi Suami-Istri Sebagai Sarana Keharmonisan Keluarga Juanda $^{1)}$ Sjanette Eveline ${ }^{2)}$
}

\author{
1) Evangelical Theological Seminary of Indonesia - Surabaya \\ E-mail: Juanda@sttii-surabaya.ac.id \\ 2) STT Adhi Wacana Surabaya \\ E-mail: Sjanetteeveline@gmail.com
}

\begin{abstract}
The smallest organization in the world is family. Beginning with husband and wife and so on developing into a family. When building a harmonious family often experience obstacles. In fact, any obstacle if you want to be investigated will come from the failure to establish husband and wife communication. Even though this is very important to avoid the division between the husband and wife. Indeed, here requires its own struggle. There needs to be awareness and willingness to learn to communicate with their partners. This is the result of the couple's maturity.
\end{abstract}

\section{Keywords: Building, Communication, Husbands and Wives, Harmony, Family}

\section{PENDAHULUAN}

Manusia adalah makhluk komunikasi, artinya manusia perlu berhubungan satu dengan yang lainnya. Manusia berhubungan satu dengan yang lainnya karena manusia saling membutuhkan satu dengan yang lainnya dan juga karena ada daya tarik dari masing-masing orang. Sebagai makhluk komunikasi maka pergaulan adalah kebutuhan manusia yang penting. Sejak lahir seseorang sudah membutuhkan orang lain, begitu juga saat masuk dalam pernikahan untuk membentuk keluarga.

Berkomunikasi dengan sesama manusia adalah sebuah relasi kehidupan yang tidak bisa dihindari. Namun interaksi ini sering kali menimbulkan konflik. Suatu hubungan yang bersifat menguras akan menyebabkan secara terus-menerus menarik cadangan emosional dan spiritual supaya bisa mengikuti tuntutan-tuntutan yang diminta. Hal ini bisa terjadi dengan pasangan atau orang tua, atau dengan mereka yang bekerja bersama, bahkan dalam kegiatan kerohanian sekalipun.

Pada awal penciptaan manusia, Allah sudah mempunyai rencana agar pria dapat bersatu dengan wanita untuk saling melengkapi dan beranakcucu memenuhi bumi. "Allah memberkati mereka, lalu Allah berfirman kepada mereka: "Beranak- cuculah dan bertambah banyak; penuhilah bumi dan taklukkanlah itu,

berkuasalah atas ikan-ikan di laut dan burungburung di udara dan atas segala binatang yang merayap di bumi." (Kej. 1:28). "Tuhan Allah berfirman:
"Tidak baik, kalau manusia itu seorang diri saja. Aku akan menjadikan penolong baginya, yang sepadan dengan dia (Kej.2:18) ${ }^{1}$

Alkitab mengajukan pernikahan sebagai lembaga yang harus sangat dihormati dan dihargai melebihi semua lembaga lain. Ibrani 13: 4 mengatakan," Hendaklah kamu semua penuh hormat terhadap perkawinan dan janganlah kamu mencemarkan tempat tidur, sebab orang-orang sundal dan pezinah akan dihakimi Allah." Perhatikan bahwa ayat ini mengatakan, " Hendaklah kamu semua penuh hormat terhadap perkawinan." Ayat ini sama sekali tidak mengatakan tentang orang-orang dalam pernikahan, tetapi tentang pernikahan itu sendiri.

Pernikahan adalah suatu sumpah diperlihatkan dengan jelas dalam Alkitab di Pengkhotbah 5:3-4. Karena pernikahan adalah sumpah yang sempurna yang dibuat di hadapan Allah yang sempurna oleh dua orang yang tidak sempurna, maka hanya Allah yang dapat membuatnya berhasil. Jangan mengharapkan kesempurnaan dari pasangan.

Pernikahan memang sempurna karena rancangan Allah, tetapi orang tidak sempurna. Lembaga pernikahan itu stabil, tidak pernah berubah. Manusia, selalu berubahubah sepanjang waktu. Menghormati lembaga pernikahan membantu melewati masa-masa ketika

\footnotetext{
${ }^{1}$ Alkitab. Jakarta: Lembaga Alkitab Indonesia, 2006.
} 
dengan pasangan menghadapi konflik yang membuat suami-istri bertindak dengan cara yang tidak hormat. Ada beberapa definisi dari pernikahan:

Pernikahan adalah blue print Sang Mahakuasa, Ketika pria menuntun pasangannya ke dalam pintu gerbang pernikahan, anda sedang membawa blueprint itu. Ketika wanita masuk dan berada dalam pernikahan, anda sedang mengerjakan blue print itu.

Blue print yang sudah dibuat itu baru dapatdikerjakan dengan baik, dengan sempurna oleh dua orang berbeda bernama pria dan wanita yang disatukan dalam pernikahan. ${ }^{2}$ Pernikahan cukup kuat bila pasangan adalah dua individu sehat dan bekerja sama untuk menghidupkan cinta. Jika pernah merasakan cinta dalampernikahan, tentu tahu bahwa semua pasangan akan melewati masa yang tidak membahagiakan-masa ketika anda tidak merasa dekat. Terlebih lagi, di dunia zaman sekarang yang sangat menyita waktu, penuh persaingan, atau menyebabkan kesedihan mendalam di hati kita. Kabar baiknya adalah bagaimanapun kisah pernikahan anda, hubungan anda tidak jauh dari kasih, perhatian, dan jangkauan Allah. Dia bisa membuka jalan. ${ }^{3}$

Kebanyakan orang berpikir bahwa pihak-pihak di dalam pernikahan suami dan istri harus saling menghormati dan saling menghargai. Ini memang benar, tetapi akhirnya bukan ini yang membuat pernikahan berhasil. Yang lebih penting adalah mereka menghormati dan menghargai pernikahan itu sendiri. Pernikahan lebih besar daripada dua orang di dalamnya, dan memang demikianlah seharusnya. Allah menetapkan lembaga pernikahan. Pernikahan ini milikNya, bukan milik manusia.

Pernikahan adalah sesuatu yang kudus di mata Allah. Lewat pernikahan, sepasang suami-istri dapat menjalankan tugasnya masing-masing. Pernikahan yang dijalani oleh suami-istri rentan dengan adanya konflik rumah tangga, hal ini dapat terjadi karena berbagai macam sebab misalnya karakter, materi, anak, mertua dan sebagainya.

Komunikasi adalah salah satu aspek yang paling mendukung dalam kehidupan manusia, sehingga manusia mengetahui akan betapa pentingnya komunikasi. Banyak masalah yang timbul sebagai akibat kurang mampunya suami-istri dalam berkomunikasi. Perselisihan, konflik, perbedaan pendapat semua dapat timbul karena kurangnya komunikasi. Keberhasilan pasangan suamiistri dalam memelihara relasi bergantung kemahirannya dalam berkomunikasi. Kata komunikasi berakar dari kata Latin co (bersama) dan unus (satu), dalam konteks relasi suami-istri bisa diartikan sebagai "dua pihak yang secara bersama-sama ingin menyatukan diri". ${ }^{4}$

2 Timotius Adi Tan, Wenny Kristianty, A Journey Of

Two Becoming One. (Jakarta: Metanoia Publishing, 2011), 7

${ }^{3}$ Elmer \& Ruth Towns, How To Build A Lasting

Marriage (Yogyakarta: Andi, 2011), 96

${ }^{4}$ Paul Subiyanto, The Handbook Of Marriage.

(Jakarta: PT Gramedia, 2011), 1
Suatu proses penyatuan antara aku dan kamu menjadi kita. Komunikasi akan memperkokoh dan memperdalam relasi dan membuahkan keintiman dan kehangatan. Oleh sebab itu, tak ada jalan pintas untuk menumbuhkan hubungan selain melalui komunikasi.

Komunikasi pada tingkat intim sulit dicapai dalam masyarakat industri modern yang menekankan produktivitas dan mengukur aktivitas manusia dalam istilah kuantitatif. Misalnya workaholik, yang harus bekerja keras agar merasa nyaman dengan diri mereka sendiri, merupakan model kesuksesan dalam kebanyakan budaya kita. ${ }^{5}$

Komunikasi menjadi salah satu penyelesaian konflik dalam rumah tangga, karena dengan adanya komunikasi tersebut maka setiap suami-istri dapat lebih terbuka dengan pasangan masing-masing dalam penyampaian atau penyelesaian masalah.

Komunikasi juga memampukan kita mengembangkan pendidikan, tehnik, bisnis, media dan setiap aspek dari budaya manusia. Bersama-sama kita merancang dan membangun gedung-gedung, jatuh cinta, membangun rumah tangga dan memainkan musik. Barangkali kemampuan ini merupakan bagian dari apa yang dinyatakan oleh kitab suci sebagai i mago dei ( gambar Allah) di dalam diri kita ( Kej. 1: 26-27) ${ }^{6}$

Setiap kali berkomunikasi, manusia secara kreatif menggunakan karunia-karunia Allah dengan memberikan kontribusi yang baik maupun yang buruk dari bagian-bagian budaya ke dalam dunia. Allah memberikan karunia berkomunikasi sehingga manusia dapat secara aktif menciptakan bersama budaya, seluruh cakupan cara hidup. Ketika berkomunikasi, manusia mengembangkan ciptaan Allah yang sejati dengan membuat dan membagikan cara hidupnya.

Ketika hubungan manusia putus dengan Allah, hati dan pikiran lebih rentan terhadap kejahatan. Dosa menyebar ke dalam semua aspek kehidupan manusia. Dosa secara mendasar merusak kemampuan manusia untuk berkomunikasi. Karena komunikasi manusia juga menderita karena dosa dan penyalahgunaan yang secara sengaja terhadap talenta komunikasi. Komunikasi yang berdosa sering kali menghalangi hadirat Allah, menyebabkan kebencian, peperangan, perceraian, bunuh diri, dan rasa kesepian. Manusia menyebarkan informasi yang egois dan manipulatif,berbohong, memfitnah, menghina dan bergosip. Rasul Yakobus secara tepat menyebutkan lidah manusia adalah "api, suatu dunia kejahatan dan mengambil tempat diantara anggotaanggota tubuh kita sebagai sesuatu yang dapat menodai seluruh tubuh dan menyalakan seluruh roda kehidupan kita, sedang ia sendiri dinyalakan oleh api neraka" (Yak.3:6). Lidah adalah "kemudi" dari

${ }^{5}$ Paul D. Meier,M.D.,Frank B. Minirth,M.D., Frank

B. Wichern, Ph.D., Donald E. Ratcliff, Ph.D., Pengantar Psikologi \& Konseling Kristen 2. (Yogyakarta: Andi, 2004), 16.

${ }^{6}$ Quentin J. Schultze, Communicating For Life (Malang: Literatur Saat, 2004), 16. 
hidup kita (Yak. 3:4) Tidak ada teori-teori komunikasi yang sempurna. Karena pandangan-pandangan dari komunikasi ini juga merupakan pandangan-pandangan bagi komunikasi, manusia harus memperhatikan pemahaman diri sendiri mengenai komunikasi itu sendiri. Dugaan-dugaan mengenai komunikasi kadangkala merupakan peta yang dipakai untuk menuntun diri sendiri melewati hidup.

Allah dalam anugerah-Nya memberikan manusia kapasitas untuk menciptakan model-model komunikasi, sehingga manusia dapat lebih memahami Allah, orang lain, ciptaan lain, dan diri sendiri. Tetapi peta komunikasi manapun dapat menyesatkan manusia bila gagal untuk mengujinya, memodifikasinya, dan menilai dalam terang firman Tuhan.

Manusia harus selalu mengingat bahwa anugerah Allah melampaui semua teori komunikasi. Allah mampu untuk masuk ke dalam budaya, untuk bercakap-cakap dengan setiap orang percaya, dan bahkan untuk mengarahkan sejarah. Manusia tidak akan mampu untuk menjelaskan atau mengendalikan semua komunikasi manusia. Manusia sekarang hanya bisa merasakan kekuatan dari firman Allah.

Komunikasi merupakan bagian dari dialog dengan ciptaan Allah. Seperti seorang kimiawan memetakan elemen-elemen, seorang sarjana komunikasi berusaha untuk mengategorikan bentuk-bentuk interaksi manusia dan menjelaskan atau memprediksikan apa yang terjadi ketika manusia berkomunikasi. Semua jenis hubungan dengan Tuhan, dengan sesama, dengan ciptaan, dan dengan diri sendiri memengaruhi budaya.

Karunia Tuhan akan komunikasi memampukan manusia untuk merancang dengan luar biasa kombinasikombinasi yang rumit. Dengan kemampuan komunikasi dari Allah memperlengkapi manusia untuk mewakili Sang Pencipta di dunia. Manusia melihat, mendengar dan berbicara di bawah kekuasaan Allah.

Komunikasi manusia berawal dari hati, dari arah yang manusia tetapkan untuk hidupnya. Manusia perlu mendengarkan lebih dahulu dan mengesampingkan pikiran dan perkataan serta agendanya sendiri cukup lama untuk mendengar dan mengerti lawan bicara. Karena komunikasi adalah sebuah seni, ini harus dengan sungguh-sungguh, dengan sabar, dan dengan cermat dipelajari sepanjang waktu.

\section{Latar Belakang Masalah}

Pernikahan adalah sebuah petualangan. Pada masa pacaran dan pertunangan yang indah, pernikahan dan bulan madu, suasananya tampak penuh dengan keajaiban. Penuh kehidupan dan semangat, pasangan yang baru menikah merasa siap menaklukkan dunia. Tidak ada pintu yang tertutup bagi mereka. Tidak ada cita-cita yang terlalu tinggi, tidak ada mimpi yang terlalu muluk. Tidak ada yang berada diluar jangkauan mereka.

Tanpa cinta takkan ada pesta pernikahan, dan tentu takkan ada pernikahan. Cinta adalah katalisator

${ }^{7}$ Alkitab Penuntun Hidup Berkelimpahan (Malang: Gandum Mas, 1996) untuk komitmen. Cintalah yang memastikan setiap pernikahan itu baik pada mulanya. Tetapi cepat atau lambat setiap pernikahan yang baik akan terbentur dengan hal-hal buruk. Dan ketika itulah pasanganpasangan yang jujur menemukan bahwa cinta, seberapa baikpun, tidak pernah cukup.

Ketika sepasang manusia memasuki pernikahan dengan yakin bahwa kesatuan bukan saja akan bertahan melainkan juga berhasil. Keyakinan akan dibangun dan didukung oleh cinta. Seseorang tidak mungkin sepenuhnya melindungi cintanya terhadap hal-hal yang memudarkannya. Terlebih lagi, cinta itu sendiri jarang cukup kuat untuk menunjang sepasang suami-istri ketika akhirnya mereka terbentur hal-hal buruk.

Salah satu tantangan pertama yang dihadapi pasangan yang sudah menikah adalah pengertian timbal balik akan harapan dan peran di dalam pernikahan. Kegagalan untuk melakukan hal ini adalah salah satu dari penyebab utama timbulnya masalah pernikahan. Suami-istri perlu mengkomunikasikan bersama mekanika pengambilan keputusan di dalam keluarga dan mengutarakan dengan jelas harapan mereka satu sama lain.

Hubungan suami-istri adalah hubungan yang paling tua dan paling unggul di antara semua hubungan manusia. Hubungan ini mendahului dan melebihi hubungan lain manapun, termasuk hubungan orang tua dan anak atau kakak dan adik. Tidak ada hubungan yang boleh lebih erat, lebih pribadi, atau lebih intim dibandingkan hubungan yang ada antara suami dan istri. Keintiman seperti ini tidak hanya melibatkan kasih, tetapi juga pengetahuan.

Suami dan istri harus mengenal satu sama lain lebih baik dibandingkan mereka mengenal orang lain manapun di dunia. Mereka harus mengetahui kesukaan dan ketidaksukaan satu sama lain, kebiasaan mereka yang mengganggu, kekuatan dan kelemahan mereka, kasih karunia mereka dan cacat karakter mereka. Singkatnya suami-istri harus mengetahui segalanya tentang satu sama lain, bahkan sifat yang tidak diinginkan yang mereka sembunyikan dari semua orang lain.

Jenis pengetahuan ini tidak otomatis. Ini tidak terjadi begitu saja hanya karena dua orang menikah. Hubungan tidak menjamin pengetahuan. Suami-istri mungkin mengamsumsikan bahwa mereka sudah saling mengenal hanya karena mereka sudah menikah. Akibatnya mereka tidak berbuat lebih, tidak pernah menduga dalamnya kepribadian satu sama lain untuk memperoleh pengetahuan yang sebenarnya dan

membangun hubungan yang dalam dan intim. Suami-istri yang benar tidak boleh mempunyai rahasia satu sama lain.

Setiap pasangan pasti pernah bertengkar. Pasangan suami-istri pernah saling tidak sependapat, mereka mempertahankan pandangan masing-masing yang dianggap benar, dan mereka melakukan apa saja untuk membuktikan alasan-alasannya. Mereka bertikai tentang karakter, materi, seks, sanak saudara, siapa yang mengerjakan pekerjaan rumah tangga, anak-anak, dan 
ratusan alasan lain yang biasanya lebih remeh daripada yang mau diakui.

Salah satu faktor ketidakcocokan dalam keluarga khususnya antara suami-istri disebabkan karena adanya perbedaan pendapat yang memicu timbulnya konflik. Konflik, suatu kata yang mengandung arti bahwa ada permasalahan di dalamnya, banyak hal yang menimbulkan konflik. Konflik dapat timbul karena adanya kesalahan dalam berkomunikasi.

Konflik dapat terjadi di mana saja, kapan saja dan dalam segala macam hubungan. Faktor kurangnya komunikasi menjadi salah satu pendorong terjadinya konflik. Sering pasangan suami-istri memuntahkan kemarahan satu sama lain hanya karena mereka tidak menyediakan waktu untuk mendengarkan lebih dahulu.

Banyak pasangan suami-istri cenderung ingin dominan satu atas yang lain. Sehingga mereka tidak sadar bahwa dorongan seperti itu terjadi karena mereka tidak punya kemampuan melakukan komunikasi yang efektif satu sama lain. Mereka ingin segera dipahami atau dimaklumi tanpa mau dan mampu membangun saluransaluran

komunikasi yang efektif terlebih dahulu. Tanpa ada komunikasi efektif, sering muncul ketidakcocokan topik pembicaraan, pembuatan kesimpulan dari hasil pembicaraan, dan biasanya gejala-gejala seperti itu mengarah pada konflik atau pertentangan pendapat yang tak bisa dipecahkan bersama.

Konflik yang intens dan berlanjut yang terjadi dalam hubungan suami-istri, oleh berbagai sebab sering menjadi pemicu bagi tantangan yang dihadapi oleh suami-istri untuk akhirnya mengambil keputusan bercerai. Terkadang banyak suami-istri yang menderita oleh karena kekurangan dalam hal komunikasi, mereka tidak mampu berbicara dengan manis tentang masalah-masalah mereka dan tidak mampu menghadapi masalah-masalah itu bersama.

Dalam masyarakat sekarang ini yang bergerak cepat dan penuh dengan stres, mendengarkan telah menjadi sebuah seni yang hilang. Kelalaian untuk mendengarkan adalah salah satu dari masalah yang paling sering berkaitan dengan komunikasi. Begitu sering manusia cenderung berkata-kata sebelum mendengarkan. Manusia dapat menghindari banyak sakit hati, kesalahpahaman, dan rasa malu apabila benar-benar belajar mendengarkan sebelum berbicara.

Kita dapat menyatakan nasihat Yakobus dengan cara ini: "Dengarkan dahulu! Jangan terburuburu berbicara, dan berhati-hatilah dengan apa yang anda ucapkan dan cara anda mengucapkannya. Jangan cepat marah karena kemarahan yang meledak hanya akan merusak pertumbuhan rohani anda." 8 Di dalam Alkitab, mendengarkan dikaitkan dengan pengetahuan dan pengertian. Berulang kali, kitab Amsal menyerukan kepada manusia untuk mendengarkan perkataan hikmat dan belajar. Berkali-kali Yesus mengimbau orang banyak untuk mendengarkan Dia: "Yesus memanggil orang banyak dan berkata kepada mereka: 'Dengar dan

${ }^{8}$ Myles Munroe, The Purpose And Power Of Love \& Marriage (Jakarta: Immanuel, 2011), 251. camkanlah' (Mat. 15:11), Yesus berkata, "Siapa bertelinga, hendaklah ia mendengar" Suami-istri adalah dua insan yang berbeda dalam hampir segala sifatnya. Sifat-sifat berbeda di antara keduanya sulit dipersatukan kecuali kalau ada kesediaan diri untuk saling memahami satu sama lain.

Manusia memiliki karakter beragam. Semua pancaindra memberi kontribusi ke dalam persekutuan dengan orang lain. Lebih dari itu, hampir semua hal yang dilakukan sebagai manusia dapat menjadi sarana berkomunikasi. Melalui kemampuan komunikasi dari setiap orang memiliki potensi untuk memberikan kontribusi dan untuk menyaksikan anugerah Allah.

Keberhasilan dan kepuasan jangka panjang dalam pernikahan sangat bergantung pada cakupan dan kedalaman suami-istri mengembangkan cara komunikasi mereka. Sangat penting bagi mereka untuk belajar mendengarkan dan mengerti satu sama lain dan merasa nyaman berbagi gagasan, perasaan, sukacita, penderitaan, harapan. dan impian mereka yang paling dalam.

\section{Identifikasi Masalah}

Pernikahan adalah salah satu peristiwa paling penting dalam kehidupan. Ketika seseorang memasuki pernikahan mereka mempunyai banyak harapan dan ideide untuk membuat pernikahan mereka bahagia. Tetapi dengan berjalannya waktu mereka mendapati pernikahan mereka tidak seindah harapan mereka. Banyak masalah yang mulai terjadi pada pasangan, baik yang baru menikah maupun yang sudah lama menikah. Masalah yang terjadi pada pasangan bisa menyebabkan pertengkaran yang bahkan mengarah ke perceraian.

Ketika dua orang yang berbeda latar belakang atau karakter, pribadi bahkan pendidikan memasuki pernikahan terkadang mereka mengerti bahwa mereka berbeda sehingga ketika mereka yang mengerti Firman Tuhan akan berkata bahwa walaupun mereka bertengkar tetapi harus diselesaikan jangan ditunda. Tetapi dengan berjalannya waktu firman Tuhan itu tidak dapat mereka laksanakan, mereka bisa bertengkar dan diam berharihari bahkan berminggu-minggu. Sehingga ketika mereka bertengkar di rumah atau di manapun bisa terbawa sampai ke gereja bahkan pelayanan mereka. Hal ini salah satunya disebabkan kurangnya kemampuan mereka untuk mengomunikasikan dengan pasangannya mengenai permasalahan yang ada.

Belakangan ini juga begitu banyak pasangan kehilangan kemampuan berkomunikasi yang terkait dengan masalah materi. Banyak pasangan yang lebih mementingkan keinginan dan pendapatnya sendiri. Seharusnya masalah materi dapat dikomunikasikan sehingga membuahkan saling pengertian guna membangun pernikahan yang kuat dan bertumbuh. Komunikasi dapat terjadi jika suami-istri bersama-sama memberi waktu, hati dan pikiran untuk mendengar pasangannya.

Komunikasi tidak dapat terjadi hanya dengan salah satu dari pihak suami atau istri yang menginginkan 
perbaikan dalam pernikahan mereka. Dalam pernikahan, saling pengertian tidak berarti meniadakan perbedaan, tetapi mampu membicarakan perbedaan tersebut serta memahami pandangan pasangannya. Karena itu untuk dapat memperbaiki pernikahan diperlukan dua orang untuk bersedia belajar, meluangkan waktu untuk mendengar dan bahkan mengampuni.Tetapi begitu banyak pasangan yang hanya pasrah atau membiarkan permasalahan itu, mereka berharap dengan berlalunya waktu pasangan mereka dapat berubah. Sehingga ketika permasalahan tersebut terulang maka pertengkaran terjadi lagi. Karena suami-istri tidak pernah membicarakannya atau mengomunikasikan permasalahan yang terjadi.

\section{Pembatasan Penelitian}

Pasangan suami-istri mungkin sudah menikah selama bertahun-tahun, tetapi tidak pernah belajar mengungkapkan perasaannya. Terkadang mereka bisa mengungkapkan perasaan tentang pasangan mereka pada pihak ketiga, seperti teman, pendeta atau psikiater, tetapi mereka mengalami kesulitan yang sangat besar untuk mengungkapkan perasaan mereka satu dengan yang lain secara langsung. Pembatasan penelitian ini mengenai pentingnya komunikasi agar suami-istri Kristen dapat memahami tentang apa itu komunikasi, sehingga akan membangun keharmonisan dalam keluarga mereka.

\section{Rumusan Masalah}

Rumusan masalah dalam pembahasan penelitian ini adalah:Pertama, apakah yang dimaksud dengan komunikasi suami-istri?Kedua, bagaimana komunikasi bisa membangun keharmonisan suami-istri?

\section{Tujuan Penulisan}

Adapun tujuan penulisan tesis ini, yaitu: Pertama, memberikan pengertian tentang makna komunikasi di antara pasangan suami-istri.Kedua, menjelaskan bahwa melalui komunikasi bisa membangun keharmonisan keluarga.

\section{Manfaat Penelitian}

Secara teoritis penulis mengharapkan agar dapat memberi penjelasan mengenai pengertian komunikasi secara umum dan pentingnya berkomunikasi bagi suamiistri. Dan komunikasi mempunyai peran penting dalam hidup berumahtangga, dan dapat mempengaruhi suatu hubungan suami-istri dalam berumahtangga.Secara praktis penulis mengharapkan suami-istri dapat belajar berkomunikasi dan mulai berlatih untuk berkomunikasi sehingga setiap permasalahan dalam rumah tangga dapat diselesaikan dengan baik, tanpa terjadinya pertengkaran apalagi perceraian.

\section{Daftar Pustaka}

Alkitab. Jakarta: Lembaga Alkitab Indonesia, 2006.
Adelaja, Sunday. Successful Marriage Takes Work. Jakarta: Shofar Media

Ministry,2008.

Arikunto, Suharsimi. Prosedur Penelitian. Jakarta: PT Rineka Cipta, 2010.

BibleWorks Versi 8.0. Norfolk, VA: BibleWorks, LLC., 2009.

Brandt Henry \& Kerry L. Skinner. Marriage God's Way. Tangerang Selatan: Gospel Press, 2004

Brizendine, Louann. Male Brain. Jakarta: PT Ufuk Publishing House, 2010.

Female Brain. Jakarta: PT

Ufuk Publishing House, 2010

Budyatna, Prof. Dr. Muhammad, M.A., Dr. Leila

Ganiem, M.Si. Teori Komunikasi

Antar Pribadi. Jakarta: Kencana Prenada

Media Group, 2011.

12 Cara Mereformasi Kehidupan Doa Anda.

Diterjemahkan oleh Meydina Arisandi.

Yogyakarta : Penerbit Andi, 2011

Cangara, Prof. Dr. H. Hafied,M.Sc. Pengantar Ilmu

Komunikasi. Jakarta: PT Raja

Grafindo Persada, 2010.

Chapman Gary. The Marriage You've Always

Wanted. Bandung: PT. Visi Anugerah

Indonesia, 2010.

Lima Bahasa Kasih. Tangerang

Selatan : Gospel Press (kelompok

Karisma Publishing), t.t.

Chang Khui Fa. Garam \& Terang bagi Keluarga.

t.k.: Pionir Jaya, 2010.

Clarke, David. Laki-laki Seperti Kerang Wanita

Seperti Linggis. Yogyakarta: Andi, 2005.

Coleman, Dr.Paul. 30 Kiat Perkawinan Yang

Bahagia. Tangerang Selatan: Binarupa

Aksara Publisher, t.t. 
Collins, Gary R. Konseling Kristen Yang Efektif. Malang: Seminar Alkitab Asia Tenggara, 1989.

Dennis \& Barbara Rainey. Growing A Spiritually Strong Family. Yogyakarta: Penerbit Kairos, 2007.

Effendy, Prof. Drs. Onong Uchjana, M.A. Ilmu Komunikasi Teori Dan Praktek.

Bandung: PT Remaja Rosdakarya, 2011.

Frost, R.N. Menemukan Kuasa Alkitab. Batam: Gospel Press, 2005.

Gary Chapman. Now You're Speaking My Language. Jakarta: Immanuel, 2012.

Gray, John, Ph.D. Men Are From mars Women are From Venus. Jakarta: PT

Gramedia Pustaka Utama, 2009.

Gunadi, Paul. How To Enjoy Your

Marriage.Yogyakarta: Gloria Graffa, 2008

Gunadi, Paul. Mengatasi Konflik Dalam Rumah Tangga. Malang: Literatur SAAT, 2008.

Heald, Cynthia. Becoming A Woman Of Prayer. Bandung: Pionir Jaya, 2010.

H.P., Rosmawaty,S.Sos., M.T. Mengenal Ilmu Komunikasi. Bandung: Widya Padjadjaran,2010.

Hocking, David \& Carole. Jatuh Cinta Lagi. Bandung: Yayasan Kalam Hidup, 1993.

International Bible Society. The Holy Bible, New International Version. Grand Rapids, Michigan: Zondervan Publishing House, 1984.

Juanda, D. R. "Melayani Kristus Dengan Karya Tulis." Journal Kerusso 1.1 (2014): $45-54$.

Juanda S.Sos., M.A. Iman Yang Berwawasan. Bandung: Yayasan Kalam Hidup, 2006.

Laffoon, Jay \& Laura. He Said She Said. Bandung : PT Visi Anugerah Indonesia, 2010.
Larosa, Arliyanus Pdt. M.Th., Esther Christiana Yuwanda, S.T.. M.Pd. Kunci Sukses Karier Pernikahan. (Bandung : Yayasan Kalam Hidup, 2009).

Laurie, Greg. Bergumul Dengan Tuhan. Jakarta: Immanuel, 2006.

Maxwell, John C. Everyone Communicates Few Connect. Jakarta: Immanuel, 2002.

Meier, Paul D.,M.D.,Frank B.Minirth,M.D.,Frank B.Wichern Ph.D.,Donald

E. Ratcliff, Ph.D. Pengantar Psikologi \& Konseling Kristen I. Yogyakarta: (PBMR) Andi, 2004. Pengantar Psikologi \&

Konseling Kristen II. Yogyakarta: (PBMR) Andi, 2004.

Mulyana, Prof. Deddy, M.A., Ph.D., Dr. Solatun, M.Si. Metode Penelitian

Komunikasi. Bandung: PT Remaja

Rosdakarya, 2008

Munroe, Myles. The Purpose And Power Of Love \& Marriage. Jakarta: Immanuel, 2011.

Novia, Windy S. Pd., Kamus Lengkap Bahasa Indonesa. Surabaya: Kashiko Press, t.t

Omartian, Stormie. Kuasa Doa Seorang Istri. Tangerang selatan: Gospel Press, 2011.

Kuasa Doa Seorang Suami.

Tangerang Selatan: Gospel Press, 2002.

Parrott,Drs. Les \& Leslie. When Bad Things

Happen To Good Marriages, Batam : Interaksara, 2002

Pease, Allan \& Barbara. Why Men Don't Listen And Women Can't Read Maps. Jakarta Selatan: Ufuk Press, 2010.

Schultze, Quentin J. Communicating For Life. Malang: Literatur Saat, 2004.

Sidjabat, B.S. Membangun Pribadi Unggul.Yogyakarta: Andi,2011. 
Stephens, Dr. Steve. Lost In Translation.

Yogyakarta: Gloria Graffa, 2009.

Sugiyono, Prof. Dr., Metode Penelitian Kuantitatif kualitatif Dan R\& D. Bandung:

CV. Alfabeta, 2012

Suprapto, Drs. Tommy, M.S., Pengantar Teori \& Manajemen Komunikasi. Jakarta:

PT Buku Kita, 2009.

Subiyanto, Paul. The Handbook Of Marriage.

Jakarta: PT Elex Media Komputindo, 2011.

Subeno Sutjipto. Indahnya Pernikahan Kristen.

Surabaya: Momentum, 2010.

Syumanjaya, Bambang \& Hanny. Family Discovery

Way. Jakarta: PT. Gramedia

Pustaka Utama,2009.

Tan,Timotius Adi, Wenny Kristianty. A Journey Of

Two Becoming One. Jakarta:

Metanoia Publishing, 2011.

Towns, Elmer \& Ruth. How to Build a Lasting

Marriage. Yogyakarta: Andi, 2011.

Towns, Elmer L. Partner Doa. Jakarta: Immanuel, 2002.

Tripp Paul David. War Of Words. Surabaya:

Momentum (Momentum Christian

Literature), 2010.

Tubbs Stewart L., Sylvia Moss. Human

Communication Prinsip-prinsip Dasar.

Bandung: PT Remaja Rosdakarya, 2008

Wijanarko, Ir. Jarot. Pemulihan Suami-istri Pria

Sejati Wanita Bijak. Jakarta: Suara

Pemulihan, 2009.

Wijanarko, Ir. Jarot. Kidung Agung Rahasia

Pernikahan Bahagia. Jakarta: Suara

Pemulihan, 2010.

Wisnuwardhani Dian, Sri Fatmawati Mashoedi.

Hubungan Interpersonal. Jakarta :

Salemba Humanika, 2012.

Wright, H. Norman. Communication @Work.

Jakarta: Immanuel, 2005.
Wright, H. Norman. Komunikasi Kunci Pernikahan Bahagia. Yogyakarta: Gloria Graffa, 2003. 